
there is a departure from ideality, as shown by the values of activity
coefficients ${ }^{5}$ and relative volatilities. The information which is now available for these four non-ideal, paraffinic-cycloparaffinic systems shows them to have broadly similar properties, which can be briefly summarized as follows.

(a) The deviations from ideality are 'positive', such that an azeotrope, if formed, is of the minimum-boiling type and the activity coefficients, calculated in the manner of Carlson and Colburns on the assumption that the vapour phase is a perfect gas, are greater than unity. The general shape of the activity-coefficient and other curves given by these systems is illustrated by data for the system 2.4-dimethylpentane-cyclohexane (Fig. 2), which also illustrates the small temperature differences which obtain.

(b) Azeotropes are formed only between paraffins and cycloparaffins of very close boiling point, as would be expected ${ }^{6}$ in mixtures of compounds of such constitutional similarity, This point is illustrated by the accompanying table.

\begin{tabular}{|c|c|c|c|}
\hline System & $\begin{array}{c}\text { Boiling } \\
\text { point } \\
\text { of pure } \\
\text { component } \\
\text { ( }{ }^{\circ} \mathrm{C} \text {. at } \\
760 \mathrm{~mm} .)\end{array}$ & $\begin{array}{c}\text { Boiling } \\
\text { point } \\
\text { difference } \\
\left({ }^{\circ} \mathrm{C} .\right)\end{array}$ & \begin{tabular}{|} 
Boiling point \\
of azeotrope \\
( $\mathrm{C}$. at \\
$760 \mathrm{~mm}$.)
\end{tabular} \\
\hline $\begin{array}{l}\text { Cyclohexane- } \\
\text { 2.4-dimethylpentane }\end{array}$ & $\begin{array}{l}80 \cdot 74 \\
80 \cdot 51\end{array}$ & 0.23 & $80 \cdot 2$ \\
\hline $\begin{array}{l}\text { Cyclohexane- } \\
\text { 2.2.3-trimethylbutane }\end{array}$ & $\begin{array}{l}80 \cdot 74 \\
80 \cdot 88\end{array}$ & $0 \cdot 14$ & $80 \cdot 15$ \\
\hline $\begin{array}{l}\text { Cyclohexane- } \\
\text { 2.2-dimethylpentane }\end{array}$ & $\begin{array}{l}80 \cdot 74 \\
79 \cdot 20\end{array}$ & $1 \cdot 54$ & $\begin{array}{c}79 \cdot 2 \\
\text { (pseudo- } \\
\text { azeotrope) }\end{array}$ \\
\hline $\begin{array}{l}\text { Methylcyclohexane- } \\
\text { 2.2.4-trimethylpentane }\end{array}$ & $\begin{array}{r}100 \cdot 93 \\
99 \cdot 24\end{array}$ & \}$\quad 1 \cdot 69$ & No azeotrope \\
\hline
\end{tabular}

(c) The volume-changes due to mixing (at $20^{\circ} \mathrm{C}$.) in the four systems are so small as to be difficult of precise determination, and in all instances are less than 0.1 per cent. The refractive indice (at $20^{\circ} \mathrm{C}$.) of the four systems show an almost exactly (to within 0.05 per cent) linear variation with composition on a volume per cent basis, in agreement with the generalization due to Ward', there being no indication of deviation from this rule as was found for many hydrocarbon systems by Heringtons.

I wish to record my thanks to the chairman of the Anglo-Iranian Oil Co., Ltd., for permission to publish these results.

Anglo-Iranian Oil Company, Limited, C. B. CoLris Research Station,
Sunbury-on-Thames Middlesex.

${ }^{1}$ Ewell, Harrison and Berg, Petrol. Eng., 16, (3), 229 (1944)

2 Birch, Habeshaw and Collis, British Prov. Patent 24302/44, fled Dec. 5,1944

3 Fenske, Ind. Eng. Chem., 24, 482 (1932).

Harrison and Berg, Ind. Eng. Chem., 38, 117 (1946).

${ }^{5}$ Carlson and Colburn, Ind. Eng. Chem., 34, 581 (1942).

"Hildebrand, "Solubility of Non-Electrolytes", 128 (2nd Edit., 1936)

? Ward, Ind. Eng. Chem., 10, 569 (1938).

' Herington, Trans. Faraday Soc., 40, 481 (1944).

\section{Cyano-ethylation of Arsines and the Formation of Arsine-amidines}

MANY examples are known of the direct union of acrylonitrile, $\mathrm{CH}_{3}$ : CH.CN, with primary and secondary amines to form the corresponding $\beta$-cyano-ethyl-amines, of types $R \mathrm{~N}\left(\mathrm{CH}_{2}, \mathrm{CH}_{2}, \mathrm{CN}\right)_{2}$ and $R^{1} R^{2} \mathrm{~N}\left(\mathrm{CH}_{2} \cdot \mathrm{CH}_{2} \cdot \mathrm{CN}\right)$ respectively

We flnd that acrylonitrile undergoes a similar combination with arsines: thus a mixture of phenyl arsine, $\mathrm{C}_{8} \mathrm{H}_{5} \mathrm{AsH}_{2}$, and two molecular equivalents of acrylonitrile furnishes the crystalline phenyl bis( $\beta$-cyano-ethyl)arsine, $\mathrm{C}_{6} \mathrm{H}_{5} \mathrm{As}\left(\mathrm{CH}_{2} \cdot \mathrm{CH}_{2} \mathrm{CN}\right)_{2}$. We have prepared a number of such tertiary arsines. The speed with which the acrylonitrile and the arsine combine depends on the particular arsine the two compounds is heated, but it may be greatly accelerated by the presence of alkaline catalysts such as sodium methoxide.

These $\beta$-cyano-arsines have various synthetic applications that we are now investigating. In particular, we find that they are readily converted by the usual reactions to the corresponding amidines : thus the cyano-arsine formulated above gives phenyl-bis $(\beta$-amidino-
ethyl)arsine, which gives crystalline salts such as the dihydrogen nitrate, $\mathrm{C}_{6} \mathrm{H}_{8} \mathrm{As}\left(\mathrm{CH}_{2} \cdot \mathrm{CH}_{2} \cdot \mathrm{C}_{\backslash \mathrm{NH}_{2}}^{\prime / \mathrm{NH}_{2}},-\overline{\mathrm{NO}}_{3}\right)_{2}$. The therapeutic action of these arsine-amidines is now being investigated.

It is noteworthy that the only arsenical amidines previously recorded $^{2}$ have had the amidino-group directly joined to a benzene ring.

University Chemical Laboratory,

$$
\text { F. G. ManN }
$$
R. C. COOKsos Cambridge.

'Linsker and Bogert, J. Amer. Chem. Soc., 65, 932 (1943) : 66, 191 (1944).
Fission of 2 : 3-Dihydropyran into Acrolein and Ethylene

IT has been suggested ${ }^{x}$ that $2: 3$-dihydrofuran (I) on heating above $400^{\circ}$ rearranges into cyclopropane aldehyde (II). By analogy, 2:3dihydropyran (III) should give cyclobutane aldehyde (IV). Experiments have shown, however, that, on heating, dihydropyran does not produce this aldehyde but splits by homogeneous reaction into acrolein and ethylene $(V)^{2}$. Whether the cyclic aldehyde intervenes in the reaction or not must still remain an open question.

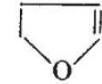

(I)<smiles>C1=COCCC1</smiles>

(III)

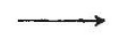

CHO

(IV)
CHO

(II)

$\mathrm{CH}_{2}=\mathrm{CH} . \mathrm{CHO}$

$\mathrm{CH}_{2}=\mathrm{CH}_{2}$

(V)
Dihydropyran is readily prepared by catalytic dehydration of tetrahydrofurfuryl alcohol, and it is surprising that acrolein has not been observed before when this reaction is carried out at sufficiently high temperatures. Kline and Turkevich ${ }^{3}$, using a thoria catalyst at $550^{\circ}$ did record the formation of low-boiling material which "polymerized on standing and had a sharp odour", but they failed to identify acrolein. Paul's experience was similar. Experiment has now shown that acrolein is formed if the conditions are right, and the yield can be as high as 62 per cent. It is important to use a selective catalys which allows the dihydropyran to be rapidly desorbed as it is formed instead of remaining attached to the surface of the catalyst and undergoing further dehydration. The best catalyst for the purpose contains equal amounts of silica and alumina. Active alumina or silica gel catalysts give only hydrocarbon products with little or no acrolein. Basic aluminium phosphate $e^{5}$, titania or thoria have interediate activity and give complex products containing some acrolein.

Full details will be given elsewhere.

University College,

London, W.C.1.

May 24.

${ }^{1}$ Wilson, J. Chem. Soc., 59 (1945)

Wilson, Brit. P., 569625. Cf., aiso, Bremner and Jones, Brit. P. 573507.

Kline and Turkevich, J. Amer. Chem. Soc., 67, 498 (1945).

Paul, R., private communication.

5 Bremner and McNeil, Brit. P., 547334.

\section{Erosion in the Sudan}

MR. ALEXANDER HOWARD, in his communication under this heading in Nature of February 23, draws a picture of the Sudan, "part desert and barren land, with scarcely a shrub or tree to be found, and otherwise sparsely covered", which is largely incorrect. The area of mixed deciduous forest in the territory exceeds 100,000 square miles in extent, while Acacia savanna forest covers a further 250,000 square miles. Even well to the north of the latitude of Khartoum $\left(16^{\circ}\right)$ rainfall is sufficient to maintain a cover of trees, bushes and grass which is of no small importance in checking erosion of soil by rain and wind. In this northern zone it is only around towns and well centres that one can come across areas which correspond to the picture drawn by Mr. Howard; it is the protection and regeneration of such areas that form one of the objectives of the Soil Conservation Board.

Department of Agriculture and Forests, (Chief Conservator of Forests)

$$
\begin{gathered}
\text { Forests Office, } \\
\text { Khartoum } \\
\text { Sudan. } \\
\text { April 11. }
\end{gathered}
$$

I AM surprised that in his capacity of chief conservator of forests, Mr. Marjoribanks appears to misunderstand the object of my communication, which was not only to stimulate public interest in this subject, but also to stress the serious situation disclosed by the report of the committee appointed by the Government to inquire into this

Mr. Marjoribanks contents himself with pointing out that there are 100,000 square miles of deciduous forest land and 250,000 square miles of Acacia savanna forests in the Sudan. He fails to mention that this leaves 650,000 square miles of desert and barren land (once no doubt forested), and it is surely with this immense area that he, as well as $\mathrm{I}$, should chiefly be concerned ?

The committee raised several vital questions, and I for one should be interested to know what measures Mr. Marjoribanks proposes to adopt to deal with these. The most important would seem to be as follows : (1) To what extent can erosion be averted by human agency ? (2) To what extent has the planting of Mesquite been carried out, and with what result? (3) Has the planting of Eucalypt been attempted, and if so with what result? (4) What answer can Mr. Marjoribanks give to the question raised by the committee as to the evil effect of over-populated areas? (5) What degree of density exists in the mixed deciduous forest areas and in those of the Acacia savanna forests?

4 Stanhope Street,

A. L. HOWARD

Euston Road, London, N.W.1. 